\title{
Sistem Informasi Eksekutif Fakultas Teknologi Komunikasi dan Informatika Universitas Nasional
}

\author{
Fendy Sulistyo, Septi Andryana*, Winarsih \\ Fakultas Teknologi Komunikasi dan Informatika, Informatika, Universitas Nasional, Jakarta, Indonesia \\ Email: ${ }^{1}$ fendysulistyo794@gmail.com, ${ }^{2, *}$ septi.andryana@civitas.unas.ac.id, ${ }^{3}$ winarsih@ civitas.unas.ac.id \\ Email penulis korespondensi: septi.andryana@civitas.unas.ac.id
}

\begin{abstract}
Abstrak-Perkembangan teknologi saat ini, dalam kegiatan pencarian informasi dan pengambilan keputusan di Fakultas Teknologi Komunikasi dan Informatika Universitas Nasional belum efektif. Karena banyaknya data yang ada menyulitkan pengguna untuk menemukan data khusus yang dibutuhkan. Seperti mencari data mahasiswa berdasarkan angkatan, agama dan jenis kelamin. Oleh karena itu, dirancanglah Sistem Informasi Eksekutif Fakultas Teknologi Komunikasi dan Informatika Universitas Nasional berbasis web sehingga pengguna bisa menemukan data yang dibutuhkan. Hasil uji coba aplikasi untuk mencari data mahasiswa, sistem dapat menampilkan hasil pencarian berdasarkan angkatan, agama dan jenis kelamin dengan tingkat keakuratan 100\%. Dalam pencarian data dosen sistem dapat menampilkan hasil pencarian berdasarkan pendidikan terakhir, keahlian dan penelitian dengan tingkat keakuratan $100 \%$. Kemudian untuk pencarian data tenaga pengajar sistem dapat menampilkan hasil pencarian berdasarkan pendidikan terakhir dan keahlian dengan tingkat keakuratan $100 \%$. Sistem juga dapat menampilkan jumlah mahasiswa berdasarkan angkatan, jumlah dosen berdasarkan keahlian dan jumlah tenaga kependidikan berdasarkan pendidikan terakhir dalam bentuk grafik.
\end{abstract}

Kata Kunci: Aplikasi, Grafik, Sistem Informasi Eksekutif

Abstract-Current technological developments, in the activities of information search and decision making at the Faculty of Communication and Information Technology of the National University have not been effective. Because the amount of data available makes it difficult for users to find the specific data needed. Like looking for student data based on class, religion and gender. Therefore, the Executive Information System of the Faculty of Communication and Information Technology of the National University was designed to be web-based so that users could find the required data. Application trial results to search for student data, the system can display search results by force, religion and gender with 100\% accuracy. In searching the system data lecturers can display search results based on their latest education, expertise and research with $100 \%$ accuracy. Then for the data search system teachers can display search results based on the latest education and expertise with $100 \%$ accuracy. The system can also display the number of students by force, the number of lecturers based on expertise and the number of education personnel based on recent education in graphical form.

Keywords: Application, Chart, Executive Information System

\section{PENDAHULUAN}

Data merupakan aspek penting di dalam organisasi baik perusahaan, lembaga, maupun instansi lainnya. Data dibutuhkan untuk keperluan perencanaan, pelaksanaan/penentuan kebijakan, pemantauan maupun evaluasi kegiatan. Data merupakan kenyataan yang menggambarkan suatu kejadian serta merupakan suatu kesatuan yang nyata, dan merupakan bentuk yang masih mentah sehingga perlu diolah lebih lanjut melalui suatu model untuk menghasilkan informasi[1]. Oleh karena itu penting untuk dilakukan pencarian data secara spesifik untuk menampilkan data secara akurat. Saat ini, dalam kegiatan pencarian informasi dan pengambilan keputusan di Fakultas Teknologi Komunikasi dan Informatika Universitas Nasional belum efektif. Karena banyaknya data yang ada menyulitkan pengguna untuk menemukan data khusus yang dibutuhkan. Seperti mencari data mahasiswa berdasarkan angkatan, agama dan jenis kelamin. Oleh karena itu, dirancanglah Sistem Informasi Eksekutif Fakultas Teknologi Komunikasi dan Informatika Universitas Nasional berbasis web sehingga pengguna bisa menemukan data yang dibutuhkan.

Beberapa peneliti sebelumnya telah melakukan penelitian serupa.Penelitian oleh Himas Adin Nugroho, Mohamad Irwan Afandi, Rizka Hadiwiyanti (2020) membuat Sistem informasi eksekutif berbasis web dengan framework codeignuter (studi kasus:PT Samudera Sarana Logistic) menggunakan bahasa pemrograman PHP dengan framework CodeIgniter dan database MySQL[2].

Penelitian berikutnya Agus Purwanto, Anggun Nugroho, Shofwan Hanief (2020) membuat perancangan system informasi eksekutif berbasis web pada upt laboraturium hayati pertanian bali untuk penentuan penyakt pada bibit tanaman menggunakan PHP, HTML, Javascrip dengan basis data My SQL[3]. Penelitian oleh Agung Brastama Putra, Rizwan Hanafi, Abdullah Maulana, Nailul Falah (2019) membuat aplikasi system informasi eksekutif dengan fasilitas drilldown dan analisis what-if menggunakan script pemograman PHP dan database MySQL[4].

Kemudian penelitian Dimas Agung Prabowo, Mohammad Irwan Afandi , Eka Dyar Wahyuni (2020) membuat Sistem informasi eksekutif akademik menggunakan data warehouse dan ad-hoc query, Bahasa pemrograman PHP dengan menggunakan framework Codeigniter[5]. Penelitian oleh Chairunnisa Guci, Fujiati (2019) membuat Sistem informasi eksekutif persediaan sparepart trado pada PT. Transporindo Agung Sejahtera menggunakan bahasa pemrograman Microsoft Visual Basic 2012 dan media penyimpanan data dengan menggunakan Microsoft SQL Server 2012[6]. 
Penelitian selanjutnya oleh Yulia Dwi Indriani, Kudang Boro Seminar, Heru Sukoco (2019) membuat sistem pendukung informasi eksekutif mobilitas sivitas akademika dan publikasi ilmiah Institute Pertanian Bogor menggunakan bahasa pemrograman php dengan framework CodeIgniter (CI) dan framework bootstraps untuk css style[7]. Penelitian oleh Imam Kukuh Pribadi, Rusmala Santi, Ricky Maulana Fajri (2016) membuat Sistem Informasi Eksekutif Berbasis Web Pada Fakultas Dakwah dan Komunikasi Universitas Islam Negeri Raden Fatah Palembang menggunakan Web service sebagai software aplikasi yang dapat terindentifikasi oleh URL dan memiliki interface yang didefinisikan[8].

Penelitian berikutnya oleh Timothy Rufus, Wasino, Ery Dewayani, Jeanny Pragantha (2019) membuat sistem informasi eksekutif penyimpanan dokumen untuk sistem penjaminan mutu internal studi kasus fakultas teknologi informasi Universitas Tarumanegara menggunakan bahasa pemograman HTML, PHP, dan MySQL[9]. Penelitian oleh Priyo Sutopo, Dedi Cahyadi, Zainal Arifin (2016) membuat sistem informasi eksekutif sebaran penjualan kendaraan roda 2 di Kalimantan timur berbasis web menggunakan bahasa pemograman HTML, PHP, dan MySQL[10]. Peneltian oleh Rinaldy Virgiawan Soepaat, Tacbir Hendro P , Faiza Renaldi (2017) membuat sistem informasi eksekutif di PT Bank Mega Bandung menggunakan bahasa pemograman PHP[11].

Penelitian berikutnya Tri Rediansyah, Faiza Renaldi, Dian Nursantika (2017) membuat sistem informasi eksekutif nasabah Bank BTN kantor cabang Bandung menggunakan bahasa pemrograman php, html, dan database Mysq1[12]. Penelitian selanjutnya Intan Putri Komara , Tacbir Hendro P, Faiza Rinaldi (2017) Membuat sistem informasi eksekutif PT.PLN (persero) Sumedang rayon Tanjungsari menggunakan bahasa pemograman PHP[13].

Pada penelitian sebelumnya yang telah dilakukan oleh beberapa peneliti, akhirnya penulis mempunyai sebuah ide membuat sistem yang berjudul "Sistem Informasi Eksekutif Fakultas Teknologi Komunikasi dan Informatika Universitas Nasional" dengan dibuatnya sistem ini maka pengguna lebih mudah mencari data-data yang diperlukan. Sistem ini dirancang menggunakan bahasa pemograman PHP dan menggunakan database MySQL.

\section{METODOLOGI PENELITIAN}

Berikut tahapan dalam melakukan penelitian, yaitu:

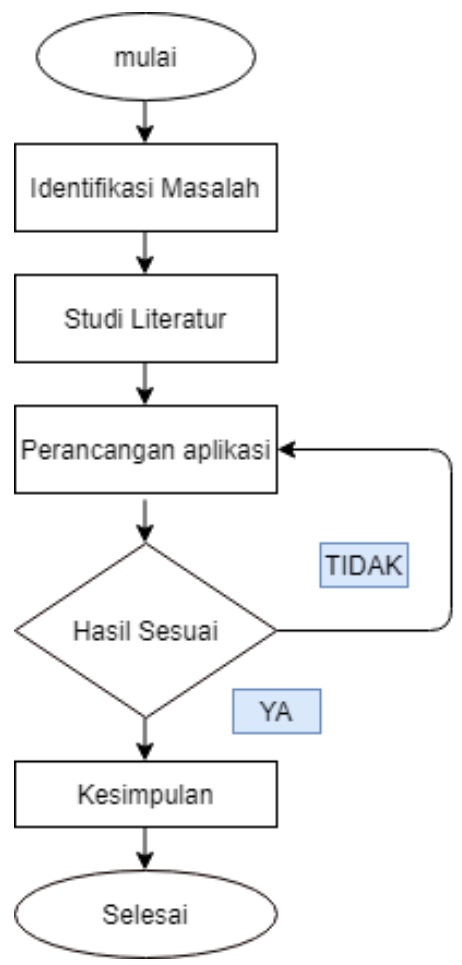

Gambar 1. Flowchart Metode Penelitian

\subsection{Identifikasi Masalah}

Identifikasi masalah yaitu melakukan identifikasi pada masalah pencarian data yang belum efektif sehingga pengguna harus mencari data satu persatu yang membutuhkan waktu dan tenaga yang lama. Hal ini berpotensi menimbulkan kesalahan yang dilakukan oleh pengguna seperti kurang teliti sehingga data yang diinginkan tidak sesuai. 


\subsection{Studi literatur}

Studi literatur sangat diperlukan untuk mendapatkan pemahaman yang lebih mengenai data yang diingikan beserta komponen-komponen untuk merancang aplikasi seperti bahasa pemograman php, database menggunakan mysql dan aplikasi pemograman sublime text. Dengan mempelajari berbagai referensi dari jurnal penelitian sebelumnya yang terkait dengan kebutuhan penelitian.

\subsection{Perancangan Aplikasi}

Selanjutnya adalah perancangan aplikasi, dimana aplikasi dirancang menggunakan bahasa pemrograman PHP serta Framework Bootstrap sebagai desain aplikasi, database yang digunakan adalah MySQL dan untuk teks editor menggunakan Sublime Text. Tahap ini juga menjelaskan semua alur proses yang ada di dalam sistem, mulai dari login hingga melakukan pencarian data seperti mahasiswa, dosen, tenaga pengajar dan laporan berupa grafik menggunakan flowchart:

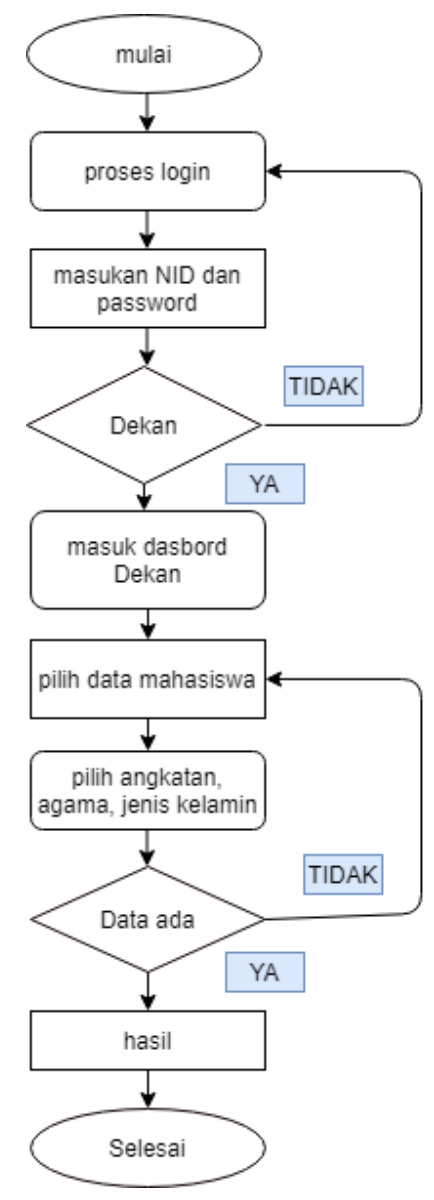

Gambar 2. Flowchart Proses Login hingga masuk tampilan data mahasiswa

Dalam gambar 2 diatas proses login dilakukan dengan menginputkan NID dan password pada form login, jika tidak terdaftar maka pengguna harus mengulangi proses login. Jika terdaftar maka pengguna akan diarahkan ke dashboard dekan, dan kemudian dapat memilih menu mahasiswa. Dihalaman tersebut pengguna dapat mencari data mahasiswa berdasarkan angkatan, agama dan jenis kelamin. Jika data yang dicari sesuai maka sisstem akan menampilan data nya, jika tidak sistem akan memberi pesan bahwa data yang dicari tidak ditemukan. Pencarian yang sama berlaku untuk menu dosen dan tenaga pengajar.

\subsection{Tahap Pengujian}

Tahap uji coba yang dibuat. Semua data hasil ujicoba dicatat secara lengkap untuk selanjutnya di analisa. analisa dilakukan dengan menentukan apakah sistem presensi ini sudah sesuai yang diharapkan atau tidak. Jika belum sesuai, maka alur penelitian akan diulangi dari tahap perancangn sistem.

\subsection{Kesimpulan}

Kesimpulan akan dilakukan jika hasil dari ujicoba sistem sudah berjalan dengan sesuai. Isi dari kesimpulan nanti nya menjadi laporan dari penelitian. 
ISSN 2614-5278 (media cetak), ISSN 2548-8368 (media online)

Available Online at https://ejurnal.stmik-budidarma.ac.id/index.php/mib

DOI $10.30865 /$ mib.v4i3.2137

\section{HASIL DAN PEMBAHASAN}

\subsection{Use Case diagram}

Gambar dibawah ini merupakan rancangan dari Use Case Diagram. Dalam sistem ini dekan sebagai user dapat melakukan login, kemudian dapat mengakses data mahasiswa, data dosen, data tenaga pengajar dan melakukan pencarian terhadap data tersebut berdasarkan kategori yang telah ditentukan. Dekan juga dapat mengakses laporan data yang ditampilkan dalam bentuk grafik.

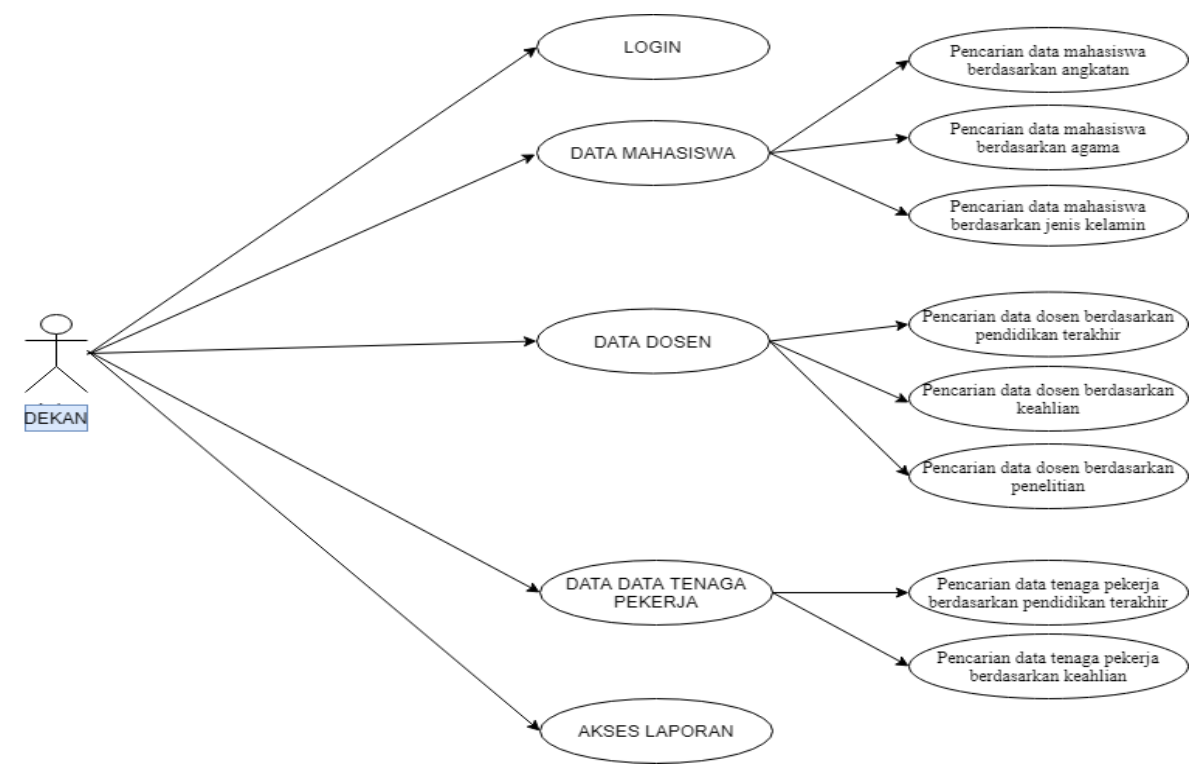

Gambar 3. Use Case

\subsection{Activity Diagram}

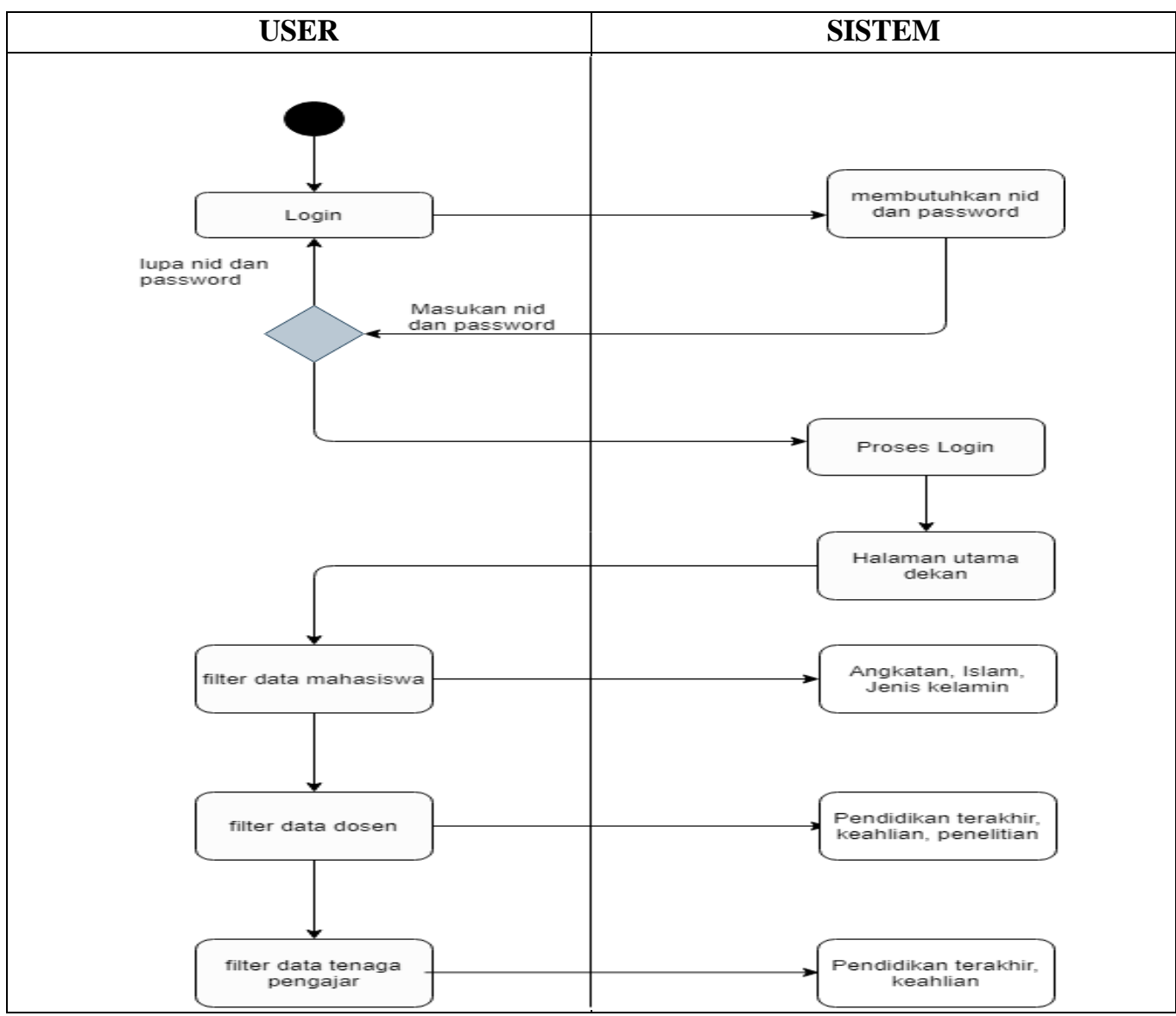

Gambar 4. Activity diagram 
JURNAL MEDIA INFORMATIKA BUDIDARMA

Volume 4, Nomor 3, Juli 2020, Page 544-551

ISSN 2614-5278 (media cetak), ISSN 2548-8368 (media online)

Available Online at https://ejurnal.stmik-budidarma.ac.id/index.php/mib

DOI 10.30865/mib.v4i3.2137

User melakukan login, sistem memerlukan nid dan password user untuk login, kemudian sistem akan memproses data nid dan password yang masuk. Jika data salah maka ulangi proses login, jika benar masuk ke halaman utama. User melakukan filter data mahasiswa, data dosen dan data tenaga pengajar. Kemudian sistem dapat menampilkan hasil filter.

\subsection{Perancangan Sequence diagram}

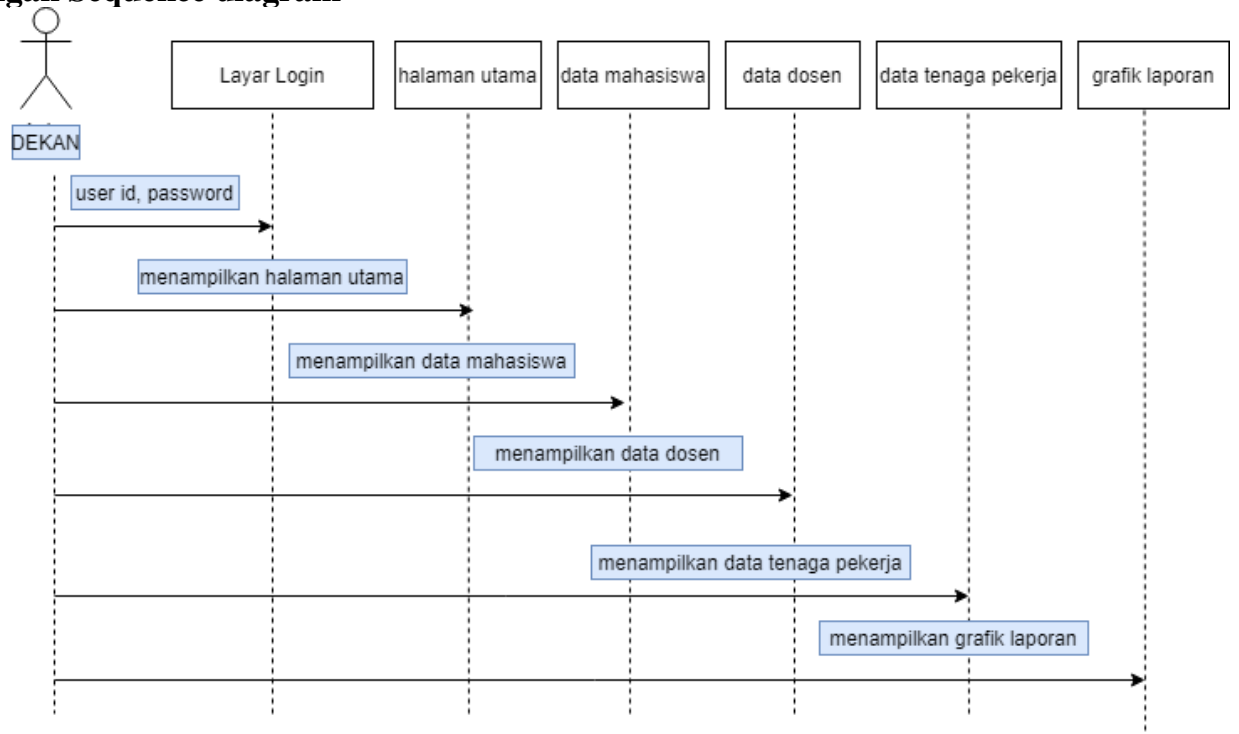

Gambar 5. Sequence diagram

\subsection{ERD (Entity Relation Diagram)}

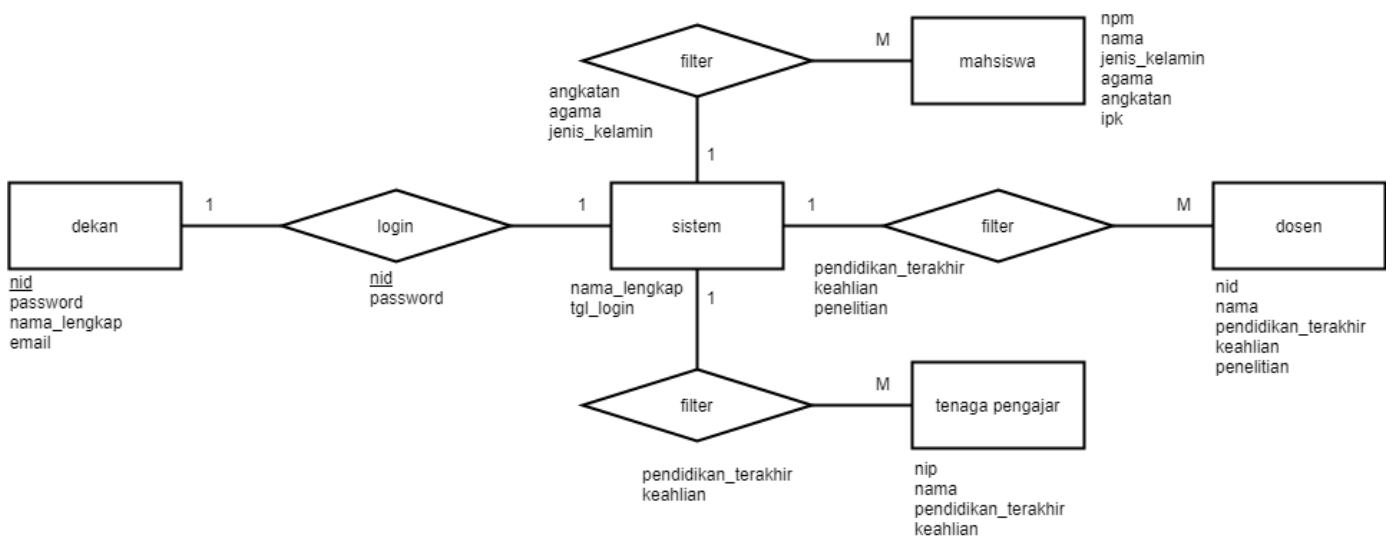

Gambar 6. ERD (Entity Relation Diagram)

\subsection{Implementasi Program}

\section{a. Tampilan Form Login}

Hasil berikut merupakan tampilan form login

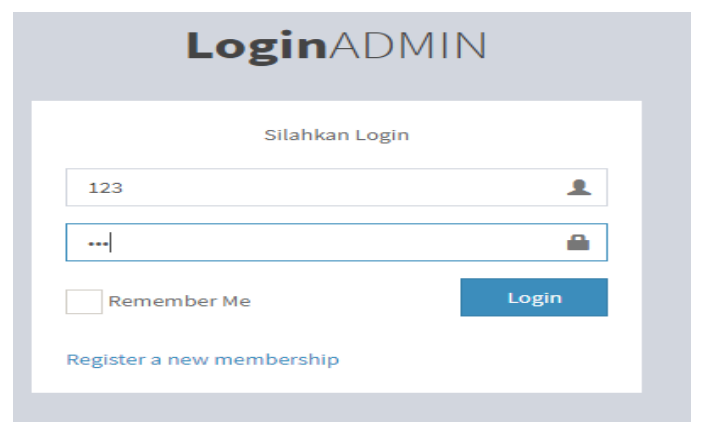

Gambar 7. Login 
JURNAL MEDIA INFORMATIKA BUDIDARMA

Volume 4, Nomor 3, Juli 2020, Page 544-551

ISSN 2614-5278 (media cetak), ISSN 2548-8368 (media online)

Available Online at https://ejurnal.stmik-budidarma.ac.id/index.php/mib

DOI 10.30865/mib.v4i3.2137

\section{b. Form Dashboard}

Pada gambar 9 berikut, merupakan tampilan dashboard pada dekan ketika user berhasil login.

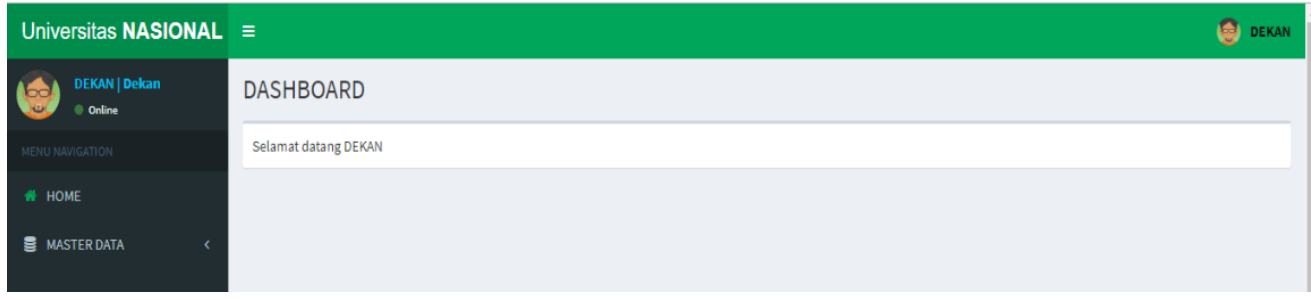

Gambar 9. Tampilan dashboard

\section{c. Form Pencarian Data Mahasiswa}

Pada gambar 10 berikut merupakan contoh pencarian dengan kategori angkatan 2020, agama islam dan jenis kelamin laki-laki.

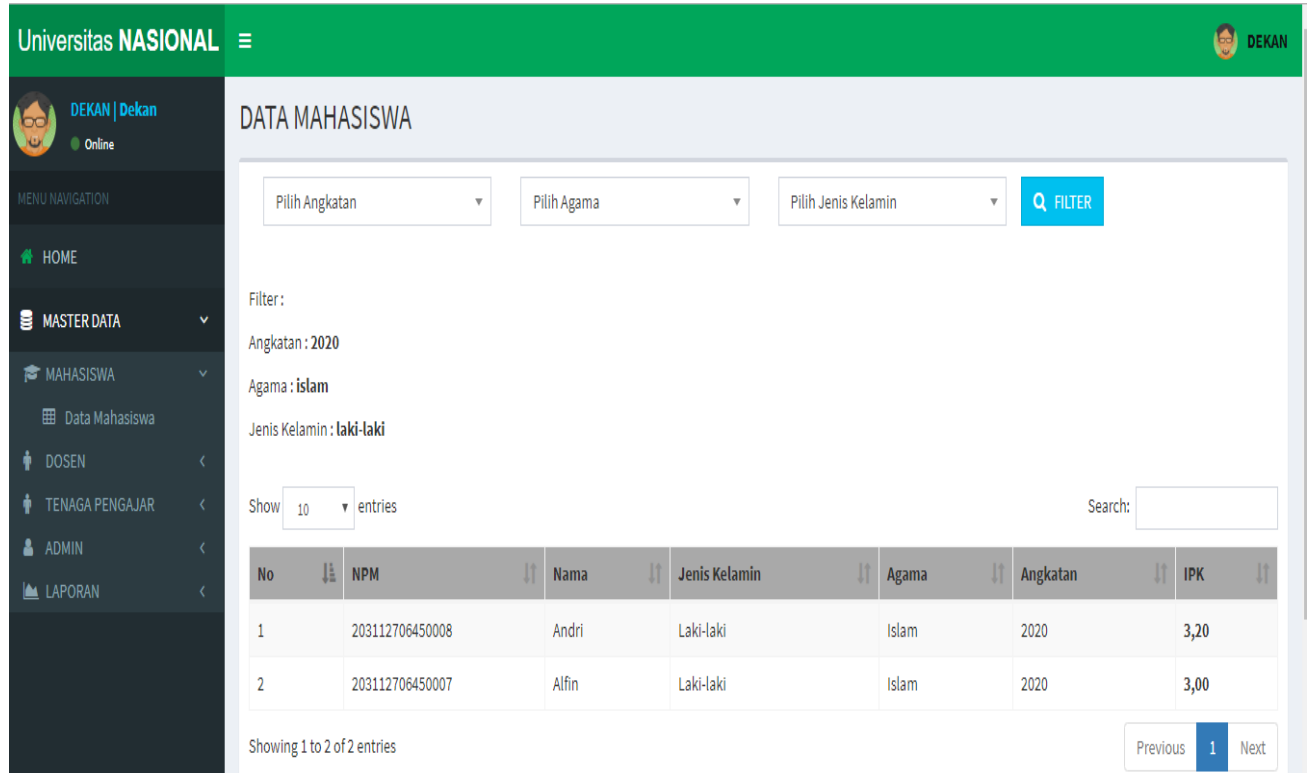

Gambar 10. Tampilan data mahasiswa

\section{d. Form Pencarian Data Dosen}

Pada gambar 11 berikut merupakan contoh pencarian dengan kategori pendidikan S3, keahlian sertifikasi dan penelitian keynote speaker.

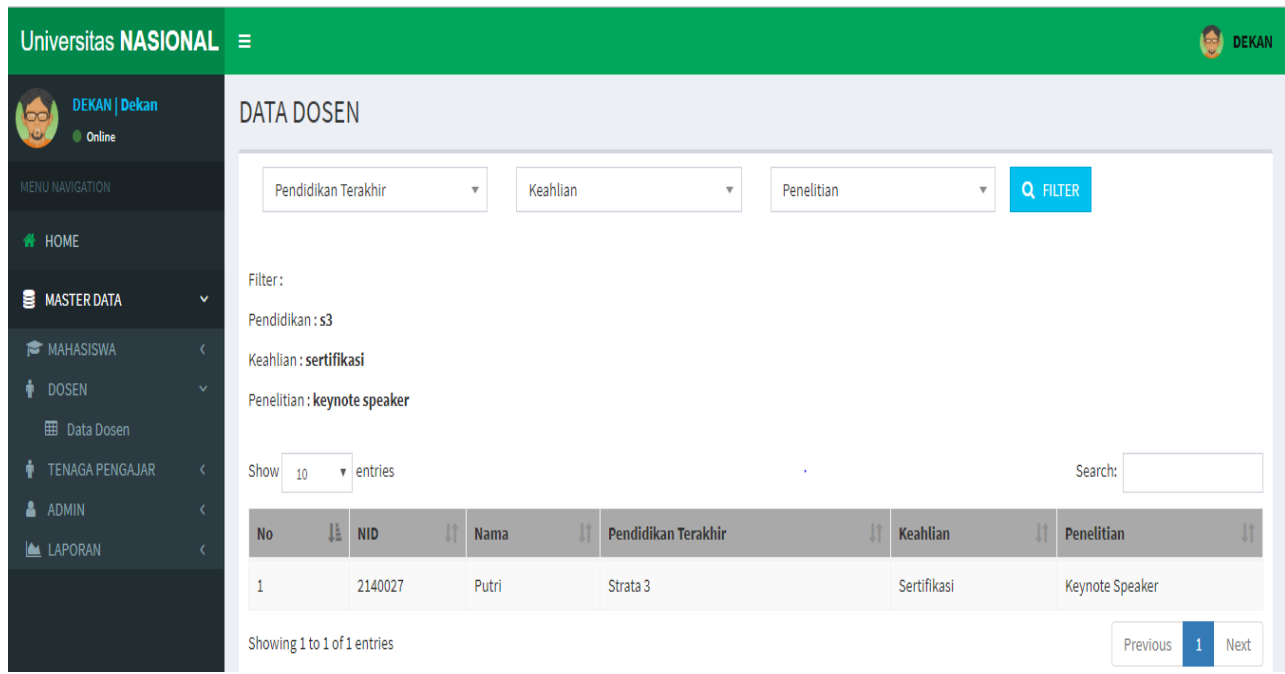

Gambar 11. Tampilan data dosen 
JURNAL MEDIA INFORMATIKA BUDIDARMA

Volume 4, Nomor 3, Juli 2020, Page 544-551

ISSN 2614-5278 (media cetak), ISSN 2548-8368 (media online)

Available Online at https://ejurnal.stmik-budidarma.ac.id/index.php/mib

DOI 10.30865/mib.v4i3.2137

e. Form Pencarian Tenaga Pengajar

Gambar berikut merupakan contoh pencarian dengan kategori pendidikan D3, keahlian pelatihan.

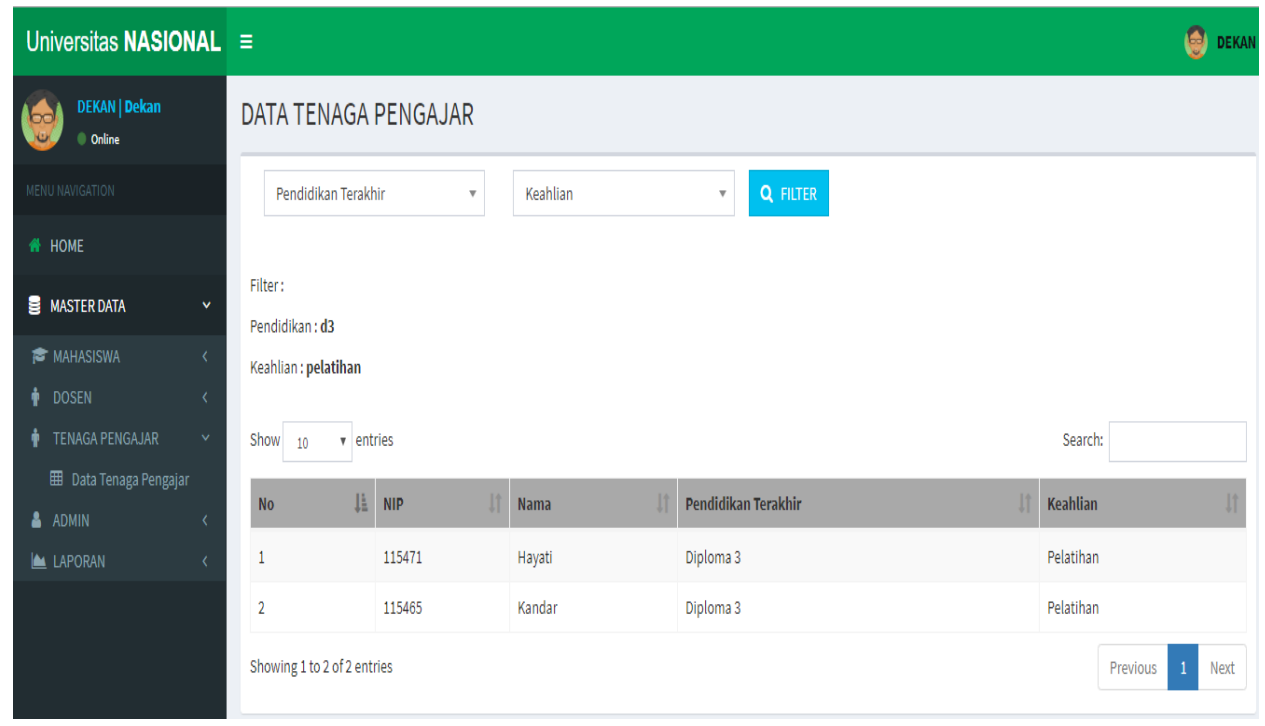

Gambar 12. Tampilan data tenaga pengajar

\section{f. Grafik Laporan}

Hasil laporan pada aplikasi ini ditampilkan dalam bentuk grafik, isi dari grafik tersebut berupa data jumlah mahsiswa pada 7 angkatan terakhir, jumlah dosen berdasarkan keahlian dan jumlah tenaga pengajar berdasarkan pendidikan terakhir.

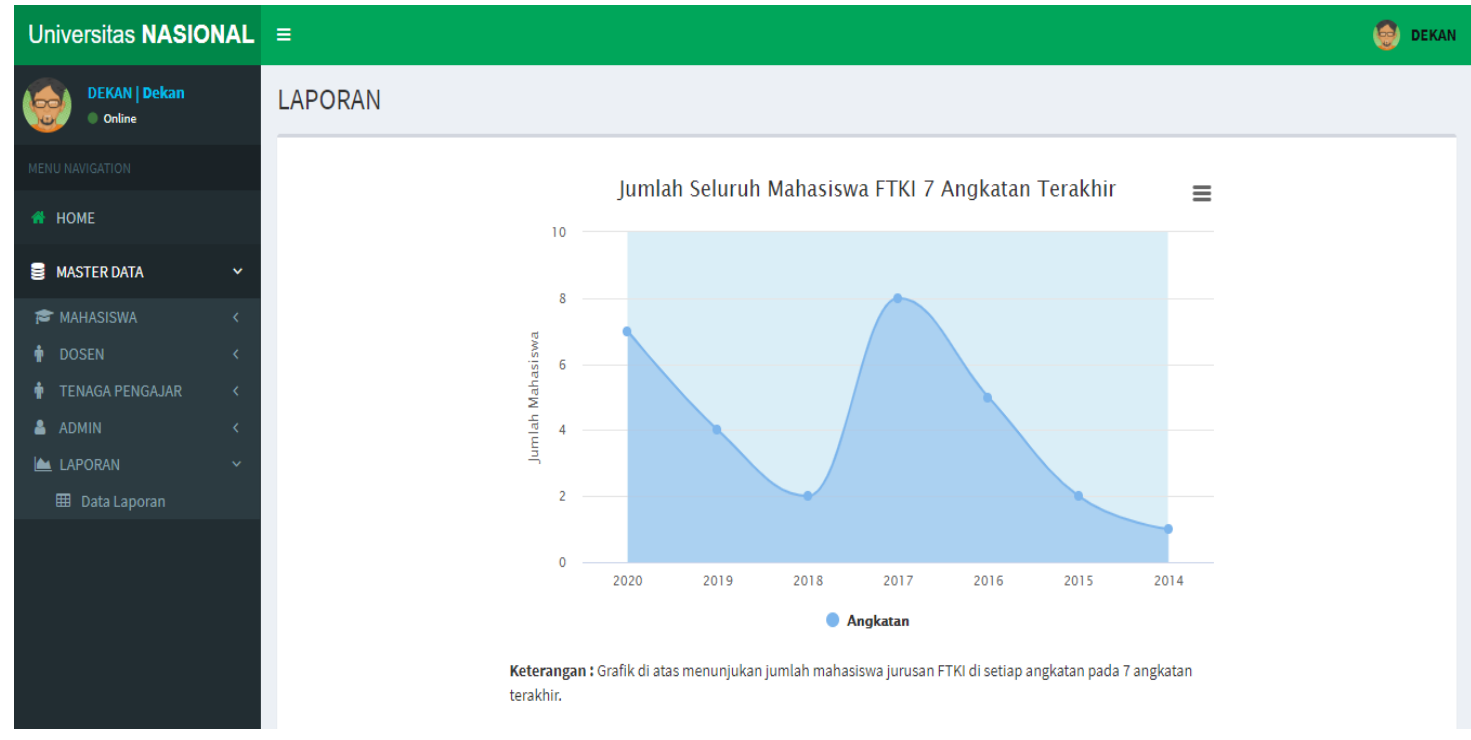

Gambar 13. Grafik mahasiswa

\section{KESIMPULAN}

Berdasarkan hasil penelitian dan pengujian ini dapat disimpulkan bahwa data mahasiswa dapat menampilkan hasil pencarian berdasarkan angkatan, agama dan jenis kelamin dengan tingkat keakuratan 100\%. Data dosen dapat menampilkan hasil pencarian berdasarkan pendidikan terakhir, keahlian dan penelitian dengan tingkat keakuratan $100 \%$. Data tenaga pengajar menampilkan hasil pencarian berdasarkan pendidikan terakhir dan keahlian dengan tingkat keakuratan 100\%. Sistem juga dapat menampilkan jumlah mahasiswa berdasarkan angkatan, jumlah dosen berdasarkan keahlian dan jumlah tenaga kependidikan berdasarkan pendidikan terakhir dalam bentuk grafik. 


\section{REFERENCES}

[1] S. Puspitorini, R. W. Astuti, and F. Al Hakim, "SISTEM INFORMASI EKSEKUTIF MANAJEMEN DATA KINERJA DOSEN PRODI TEKNIK INFORMATIKA STMIK NURDIN HAMZAH,” pp. 624-632, 2014.

[2] H. A. Nugroho, M. I. Afandi, and R. Hadiwiyanti, "SISTEM INFORMASI EKSEKUTIF BERBASIS WEB DENGAN FRAMEWORK CODEIGNITER ( STUDI KASUS : PT SAMUDERA SARANA LOGISTIK )," vol. 1, no. 1, pp. 248-254, 2020.

[3] A. Purwanto, S. Hanief, and A. Nugroho, "Perancangan sistem informasi eksekutif berbasis web pada upt laboratorium hayati pertanian bali untuk penentuan penyakit pada bibit tanaman," no. February, 2020, doi: 10.36002/jutik.v6i2.1054.

[4] A. B. Putra, R. Hanafi, A. Maulana, and N. Falah, "Aplikasi Sistem Informasi Eksekutif Dengan Fasilitas Drilldown Dan Analisis What-If," J. Sist. Inf. dan Bisnis Cerdas, vol. 12, no. 1, pp. 41-50, 2019, doi: 10.33005/sibc.v12i1.1587.

[5] D. A. Prabowo, M. I. Afandi, and E. D. Wahyuni, "SISTEM INFORMASI EKSEKUTIF AKADEMIK MENGGUNAKAN DATA WAREHOUSE DAN AD-HOC QUERY,” vol. 1, no. 1, pp. 175-182, 2020.

[6] C. Guci and Fujiati, "SISTEM INFORMASI EKSEKUTIF PERSEDIAAN SPAREPART TRADO PADA PT. TRANSPORINDO AGUNG SEJAHTERA,” vol. 6, no. C, pp. 1-6, 2019.

[7] Y. D. Indriani, K. B. Seminar, and H. Sukoco, "SISTEM PENDUKUNG INFORMASI EKSEKUTIF MOBILITAS SIVITAS AKADEMIKA DAN PUBLIKASI ILMIAH INSTITUT PERTANIAN BOGOR,” vol. 16, no. 2, pp. 1-9, 2013.

[8] I. K. Pribadi, R. Santi, and R. M. Fajri, "Sistem Informasi Eksekutif Berbasis Web Pada Fakultas Dakwah dan Komunikasi Universitas Islam Negeri Raden Fatah Palembang,” vol. 2, pp. 21-30, 2016.

[9] T. Rufus et al., "SISTEM INFORMASI EKSEKUTIF PENYIMPANAN DOKUMEN ONLINE UNTUK SISTEM PENJAMINAN MUTU INTERNAL STUDI KASUS FAKULTAS TEKNOLOGI INFORMASI UNIVERSITAS TARUMANAGARA," vol. 2, pp. 153-160, 2019.

[10] P. Sutopo, D. Cahyadi, and Z. Arifin, "Sistem Informasi Eksekutif Sebaran Penjualan Kendaraan Bermotor Roda 2 di Kalimantan Timur Berbasis Web," Inform. Mulawarman J. Ilm. Ilmu Komput., vol. 11, no. 1, p. 23, 2016, doi: 10.30872/jim.v11i1.199.

[11] R. Virgiawan Soepaat, T. Hendro P, and F. Renaldi, "Sistem Informasi Eksekutif di PT Bank Mega Bandung," Pros. SNATIF Ke -4, pp. 357-364, 2017.

[12] T. Rediansyah, F. Renaldi, and D. Nursantika, "SISTEM INFORMASI EKSEKUTIF NASABAH BANK BTN KANTOR CABANG BANDUNG," Pros. SNATIF ke-4 Tahun 2017, vol. 1, pp. 153-160, 2017, doi: 10.2298/PAN0903301G.

[13] I. P. Komara, H. T. P, and F. Rinaldi, "SISTEM INFORMASI EKSEKUTIF PT. PLN (PERSERO) SUMEDANG RAYON TANJUNGSARI,” Pros. SNATIF ke-4 Tahun 2017, pp. 783-790, 2017, doi: 10.2298/PAN0903301G. 